\title{
Nutritional status of children hospitalized in Tabriz Paediatric Hospital, Islamic Republic of Iran, 2008
}

\author{
A.M. Mahdavi, ${ }^{1}$ A. Ostadrahimi ${ }^{2}$ and A. Safaiyan ${ }^{7}$
}

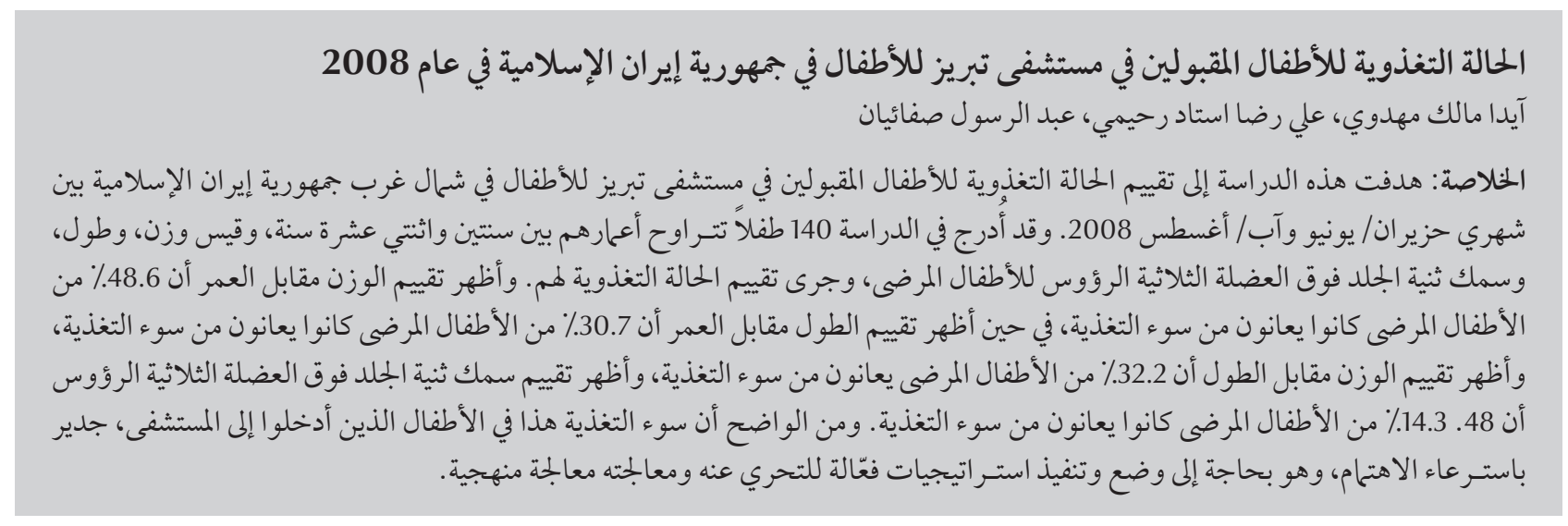

ABSTRACT This study aimed to evaluate the nutritional status of children consecutively admitted as inpatients to Tabriz Paediatric Hospital in the north-west of the Islamic Republic of Iran between June and August 2008. A total of 140 children aged 2-12 years were included. Patients' weight, height and triceps skinfold thickness (TSFT) were measured, and nutritional status was evaluated. Evaluation of weight-for-age, height-for-age, weight-forheight and TSFT showed that 48.6\%, 30.7\%, 32.2\% and $14.3 \%$ of the patients, respectively, were malnourished. Malnutrition among hospitalized children is worthy of attention, and effective strategies for systematic screening and treatment of malnutrition need to be developed and implemented.

État nutritionnel des enfants hospitalisés à I'hôpital pédiatrique de Tabriz (République islamique d'Iran) en 2008

RÉSUMÉ La présente étude visait à évaluer l'état nutritionnel des enfants admis consécutivement à séjourner à I'hôpital pédiatrique de Tabriz, au nord-ouest de la République islamique d'Iran, entre juin et août 2008. Au total, 140 enfants âgés de 2 à 12 ans ont été inclus. Les enfants ont été pesés, leur taille et l'épaisseur du pli cutané tricipital ont été mesurés et l'état nutritionnel a été évalué; 48,6 \% des enfants souffraient de malnutrition selon l'évaluation du rapport poids/âge, 30,7 \% selon celle du rapport taille/âge, 32,2 \% selon le rapport poids/taille, et 14,3\% selon la mesure de l'épaisseur du pli cutané tricipital. La malnutrition chez les enfants hospitalisés mérite une attention particulière et des stratégies efficaces pour un dépistage systématique et pour un traitement de la malnutrition doivent être élaborées et mises en œuvre.

${ }^{7}$ School of Health \& Nutrition; ${ }^{2}$ Nutrition Research Centre, School of Health \& Nutrition, Tabriz University of Medical Sciences, Tabriz, Islamic Republic of Iran (Correspondence to A.M. Mahdavi: aidamalek@gmail.com).

Received: 14/04/09; accepted: 26/07/09 


\section{Introduction}

Growth depends on a constant supply of essential nutrients in sufficient amounts and proportions. Failure to thrive occurs when growth fails as a result of inadequate nutrition. Inadequate nutrition can be caused by inadequate intake, increased losses, or increased requirements [1]. Malnutrition is a major health problem in hospitalized paediatric patients [2] and is reported as varying between $21 \%$ and $80 \%$ in proportion with the level of development of the countries [1]. Malnutrition has considerable health impacts on the physical, social and economical status of patients $[3,4]$. It may also affect the quality of life of patients [5]. Therefore, it is essential that patients who are malnourished or at risk of developing malnutrition be identified soon after admission so that nutritional support may be provided to correct nutritional changes and improve the patient's prognosis[6].

Nutritional assessment is a comprehensive approach to defining nutrition status that uses medical, nutrition, and medication histories; physical examination; anthropometric measurements and laboratory data [7]. Meanwhile anthropometric evaluation is very important for early discovery of the patients with high risk of malnutrition. For this reason, it is necessary to measure at least weight and height of the newly hospitalized patients, and to calculate the required anthropometric values [8].

The aim of this study was to evaluate children's nutritional status at the moment of their hospitalization in the paediatric hospital in Tabriz, one of the major cities in the north-west of the Islamic Republic of Iran in order to provide baseline information to set up a regional population-based centre to control and prevent malnutritionrelated disorders in the area.

\section{Methods}

\section{Subjects}

One hundred and forty children (2-12 years of age) were included in the study. All subjects were hospitalized consecutively in the Paediatric Hospital of Tabriz University of Medical Sciences [including surgical, infectious diseases, oncology, ear/nose/throat, and internal medicine (gastroenterology, nephrology, respiratory, neurology, cardiology, metabolic disorder) wards] between June and August 2008. Patients hospitalized in emergency, neonatal intensive care and neonatal special care units were excluded from the study.

The paediatric hospital, located in Tabriz city, is the only specialty and subspecialty centre for children in the north-west of the country and it delivers secondary and tertiary care for paediatric patients. The study was approved by the Ethics Committee of Tabriz University of Medical Sciences. All of the parents (responsible caregivers) were made aware of the content of the study and written informed consent was obtained in each case. The details of the study were then also explained to the children who were participating.

\section{Anthropometric measurements}

While $\mathrm{W} / \mathrm{A}$ and $\mathrm{W} / \mathrm{H}$ are considered suitable for cases with acute malnutrition (underweight and wasting), $\mathrm{H} / \mathrm{A}$ scores are sound indicators of chronic malnutrition (stunting) [9]. In our study, given these 2 types of malnutrition, and in accordance with the various nutritional indicators for the different age groups, we used more than 1 anthropometric measurement.

All subjects were assessed for anthropometric parameters [weight, height and triceps skinfold thickness (TSFT)] by a trained nutritionist during the first 3 days of hospitalization. All measurements were carried out by the same person.
Body weight was measured to the nearest $0.1 \mathrm{~kg}$ using a Seca scale with the participants barefoot and wearing light clothing. Height was measured to the nearest $0.1 \mathrm{~cm}$ using a mounted tape; the children were barefoot with arms hanging freely at their sides.

To evaluate a patient's nutritional status, weight-for-age (W/A), heightfor-age $(\mathrm{H} / \mathrm{A})$ and weight-for-height $(\mathrm{W} / \mathrm{H})$ were calculated $[1]$.

- $\mathrm{W} / \mathrm{A}=[$ observed weight $/$ median weight (same age and sex) $] \times 100$;

- $\mathrm{H} / \mathrm{A}=[$ observed height $/$ median height (same age and sex) ] × 100;

- $\mathrm{W} / \mathrm{H}=[$ observed weight $/$ median height (same height and sex) $] \times 100$.

Malnutrition was defined by the criteria established by Waterlow, $75 \%-90 \%, 60 \%-74 \%$, and $<60 \%$ of the median sex-specific reference values of W/A of this population; $90 \%-95 \%$, $85 \%-89 \%$, and $<85 \%$ of the median sex-specific reference values of $\mathrm{H} / \mathrm{A}$ of this population; $81 \%-90 \%, 70 \%-80 \%$ and $<70 \%$ of the median sex-specific reference values of $\mathrm{W} / \mathrm{H}$ of this population were considered to indicate mild, moderate and severe malnutrition respectively [10].

TSFT was measured with a skinfold calliper to the nearest $0.1 \mathrm{~mm}$ at the midpoint of the arm between the tips of the acromion process and the olecranon process. The mean of 3 measurements was used. Criteria used to define malnutrition were TSFT values $<10$ th centile of reference data based on the results of the National Health and Nutrition Examination Survey [11].

\section{Statistical analysis}

Statistical analysis was performed with SPSS, version 11.5. Continuousvariables were presented as mean and standard error of the mean (SEM), while categorical variables were presented as number and percentage. The chi-squared test was used to compare differences in categorical variables and the independent $t$-test for continuous variables between 
boys and girls. $P<0.05$ was considered to indicate statistical significance.

\section{Results}

Table 1 shows the basic characteristics of the study subjects. The study sample comprised 67 girls (47.9\%) and 73 boys (52.1\%), with a mean age of 6.32 (SEM 0.32 ) years for girls and 6.53 (SEM 0.34) years for boys. The length of hospital stay varied from 1 to 36 days. There were no significant differences in demographic data between the 2 groups $(P>0.05)$.

Table 2 shows the anthropometric data of the children. The mean of W/A was significantly higher in boys than in girls $(P<0.05)$. There were no significant differences in means of other anthropometric data.

According to W/A data, 68 (48.6\%) of the patients studied were malnourished, 20 (14.3\%) moderately/severely so (Table 3). From the H/A data, 43 (30.7\%) of the patients studied were malnourished, 12 (8.6\%) moderately/ severely so. According to $\mathrm{W} / \mathrm{H}$ data, 45 (32.2\%) of the patients studied were malnourished, 13 (9.3\%) moderately/ severely so. TSFT results indicated that 20 (14.3\%) of the patients studied were malnourished.

The only significant difference between boys and girls was in $\mathrm{W} / \mathrm{H}$ data $(P=0.005)$.

\section{Discussion}

In our study we found that $48.6 \%$ of the children were underweight (low W/A), 30.7\% were stunted (low H/A) and $32.2 \%$ were wasted (low $\mathrm{W} / \mathrm{H}$ ). Our findings also indicate that according to TSFT results, 20 (14.3\%) of the patients studied were malnourished.

Consistent with our findings, Dogan et al. [1], in a study in Turkey covering 528 patients with mean age 5.8 years, chronic malnutrition was found in $27 \%$ of cases according to $\mathrm{H} / \mathrm{A}$, and acute malnutrition was found in $52.4 \%$ and $40.9 \%$ of cases according to W/A and $\mathrm{W} / \mathrm{H}$ results respectively. In addition, with regard to sex, no statistically

\begin{tabular}{|c|c|c|c|c|c|c|}
\hline \multirow[t]{2}{*}{ Characteristic } & \multicolumn{2}{|c|}{ All children $(n=140)$} & \multicolumn{2}{|c|}{ Boys $(n=73)$} & \multicolumn{2}{|c|}{ Girls $(n=67)$} \\
\hline & Mean & SEM & Mean & SEM & Mean & SEM \\
\hline Age (years) & 6.43 & 0.23 & 6.53 & 0.34 & 6.32 & 0.32 \\
\hline No. offamily members & 4.44 & 0.17 & 4.55 & 0.28 & 4.33 & 0.18 \\
\hline No. of children & 2.06 & 0.08 & 2.11 & 0.11 & 2.00 & 0.12 \\
\hline \multirow[t]{2}{*}{ Length of hospital stay (d) } & 5.37 & 0.44 & 5.30 & 0.67 & 5.45 & 0.57 \\
\hline & No. & $\%$ & No. & $\%$ & No. & $\%$ \\
\hline \multicolumn{7}{|l|}{ Birth order } \\
\hline 1st & 65 & 46.4 & 30 & 41.1 & 35 & 52.2 \\
\hline 2nd & 54 & 38.6 & 31 & 42.5 & 23 & 34.3 \\
\hline 3rd \& higher & 21 & 15.0 & 12 & 16.4 & 9 & 13.4 \\
\hline \multicolumn{7}{|l|}{ Father's education } \\
\hline Illiterate & 14 & 10.0 & 9 & 12.3 & 5 & 7.5 \\
\hline Literate & 118 & 84.4 & 60 & 82.2 & 58 & 86.6 \\
\hline Higher education ${ }^{a}$ & 8 & 5.7 & 4 & 5.5 & 4 & 6.0 \\
\hline \multicolumn{7}{|l|}{ Mother's education } \\
\hline Illiterate & 22 & 15.7 & 12 & 16.4 & 10 & 14.9 \\
\hline Literate & 115 & 82.1 & 59 & 80.8 & 56 & 83.5 \\
\hline Higher education $^{\mathrm{a}}$ & 3 & 2.1 & 2 & 2.7 & 1 & 1.5 \\
\hline \multicolumn{7}{|l|}{ Father's job $^{b}$} \\
\hline High/moderate level & 6 & 4.3 & 4 & 5.5 & 2 & 2.9 \\
\hline Low level & 53 & 37.9 & 22 & 30.1 & 31 & 46.2 \\
\hline Very low level & 81 & 57.8 & 47 & 64.4 & 34 & 50.7 \\
\hline \multicolumn{7}{|l|}{ Mother's job } \\
\hline Housewife & 134 & 95.7 & 68 & 93.2 & 66 & 98.5 \\
\hline Employed & 6 & 4.3 & 5 & 6.8 & 1 & 1.5 \\
\hline
\end{tabular}

${ }^{a}$ University plus.

${ }^{b}$ High/moderate = management, skilled worker, etc.; low = sales assistant, semi- skilled worker, etc.; very low level = farmer, service worker, labourer, etc. $\mathrm{P}>0.05$ (not significant).

$S E M=$ standard error of the mean . 


\begin{tabular}{|c|c|c|c|c|c|c|}
\hline \multirow{2}{*}{ Characteristic } & \multicolumn{2}{|c|}{ All children $(n=140)$} & \multicolumn{2}{|c|}{ Boys $(n=73)$} & \multicolumn{2}{|c|}{ Girls $(n=67)$} \\
\hline & Mean & SEM & Mean & SEM & Mean & SEM \\
\hline Weight $(\mathrm{kg})^{a}$ & 20.15 & 0.67 & 21.01 & 0.99 & 19.22 & 0.89 \\
\hline Height $(\mathrm{cm})^{\mathrm{a}}$ & 112.75 & 1.55 & 113.70 & 2.17 & 111.72 & 2.22 \\
\hline Weight-for-age (\%) & 89.98 & 1.39 & 92.65 & 2.11 & 87.06 & 1.73 \\
\hline Height-for-age (\%) ${ }^{a}$ & 96.83 & 0.46 & 96.87 & 0.64 & 96.78 & 0.67 \\
\hline Weight-for-height (\%) & 95.58 & 1.06 & 97.01 & 1.47 & 94.02 & 1.52 \\
\hline Triceps skinfold thickness $(\mathrm{mm})^{\mathrm{a}}$ & 9.99 & 0.26 & 10.12 & 0.37 & 9.86 & 0.37 \\
\hline
\end{tabular}

${ }^{a} \mathrm{P}>0.05$ (not significant); ${ }^{b} \mathrm{P}<0.05$.

$S E M=$ standard error of the mean.

significant difference was found for the mean values of $\mathrm{H} / \mathrm{A}$ and $\mathrm{W} / \mathrm{H}$, which is similar to our study. However, this study found no statistically significant difference regarding the mean value of $\mathrm{W} / \mathrm{A}$, which is in contrast with our findings.

Consistent with our TSFT results, Pawellek, Dokoupil and Koletzko reported that their TSFT measure indicated $17.2 \%$ malnourishment in hospitalized children [11].

Findings on the nutritional status vary considerably: studies in preschool children in Nigeria and South Korea reported acute malnutrition rates of $7.4 \%$ and $16.5 \%$, and chronic malnutrition rates of $60.7 \%$ and $38.2 \%$ respectively $[3,12]$. In Thailand, $55 \%$ of patients aged $1-15$ years suffered from acute malnutrition [13] while in Mexico varying degrees of malnutrition were reported in $72.2 \%$ of hospitalized children [14]. According to 2 studies from different areas of Turkey, malnutrition rates in the country varied between $55.1 \%$ and $56.6 \%[15,16]$. Ferreira and França in Brazil reported that $71.2 \%$ of the sampled children suffered from malnutrition at the time of hospitalization according to W/A figures [8].

In contrast with our findings, another study covering 3152 preschool children in Turkey showed that only $21 \%$ of the children were stunted, $3 \%$ were wasted and $10 \%$ were underweight [17].

In more developed countries malnutrition has been reported to be
$24.1 \%$ in children admitted to a tertiary care centre in Germany [11], $24.5 \%$ children admitted to a tertiary care centre in Boston, United States of America (USA), based on $<90 \%$ of median weight for height [18] and $7 \%$ in children admitted to paediatrics or paediatric surgery at the children's hospital in Glasgow, United Kingdom, also using $<90 \%$ of median $\mathrm{W} / \mathrm{H}$ of national reference data [19]. In addition, in a study in the Netherlands among all hospitalized children, $15 \%$ had acute and $20 \%$ had chronic malnutrition [20]. With a different cut-off point $(-2$ standard deviations below mean $\mathrm{W} / \mathrm{H}$ of the USA National Center for Health Statistics centiles), a lower prevalence rate (14\%) of malnutrition was found among 255 patients aged 3 months to 18 years admitted to a children's hospital in Birmingham, United Kingdom [21]. A study in Canada in 1977 found $20 \%$ of hospitalized children to have at least 1 subnormal anthropometric variable [22]. A survey of Cooper et al. In the USA revealed that $54 \%$ of the patients were malnourished $(<90 \%$ of standard W/H after McLaren) [23].

\begin{tabular}{|c|c|c|c|c|c|c|}
\hline \multicolumn{7}{|c|}{$\begin{array}{l}\text { Table } 3 \text { Nutritional status of hospitalized children in Tabriz, 2008, according to } \\
\text { anthropometric measurements }\end{array}$} \\
\hline \multirow[t]{2}{*}{ Parameter \& nutrition status } & \multicolumn{2}{|c|}{$\begin{array}{l}\text { All children } \\
(n=140)\end{array}$} & \multicolumn{2}{|c|}{$\begin{array}{l}\text { Boys } \\
(n=73)\end{array}$} & \multicolumn{2}{|c|}{$\begin{array}{c}\text { Girls } \\
(n=67)\end{array}$} \\
\hline & No. & $\%$ & No. & $\%$ & No. & $\%$ \\
\hline \multicolumn{7}{|l|}{ Weight-for-age ${ }^{a}$} \\
\hline Normal & 72 & 51.4 & 40 & 54.8 & 32 & 47.8 \\
\hline Mild malnutrition & 48 & 34.3 & 26 & 35.6 & 22 & 32.8 \\
\hline Moderate/severe malnutrition & 20 & 14.3 & 7 & 9.6 & 13 & 19.4 \\
\hline \multicolumn{7}{|l|}{ Height-for-age ${ }^{a}$} \\
\hline Normal & 97 & 69.3 & 52 & 71.2 & 45 & 67.2 \\
\hline Mild malnutrition & 31 & 22.1 & 17 & 23.3 & 14 & 20.9 \\
\hline Moderate/severe malnutrition & 12 & 8.6 & 4 & 5.5 & 8 & 11.9 \\
\hline \multicolumn{7}{|l|}{ Weight-for-height ${ }^{b}$} \\
\hline Normal & 95 & 67.9 & 49 & 67.1 & 46 & 68.7 \\
\hline Mild malnutrition & 32 & 22.9 & 22 & 30.1 & 10 & 14.9 \\
\hline Moderate/severe malnutrition & 13 & 9.3 & 2 & 2.7 & 11 & 16.4 \\
\hline \multicolumn{7}{|l|}{ Triceps skinfold thickness ${ }^{a}$} \\
\hline Normal & 120 & 85.7 & 66 & 90.4 & 54 & 80.6 \\
\hline Malnutrition & 20 & 14.3 & 7 & 9.6 & 13 & 19.4 \\
\hline
\end{tabular}

${ }^{a} \mathbf{P}>0.05$ (not significant); ${ }^{b} \mathrm{P}=0.005$. 
Many factors, including variations between the countries that conducted the studies, diversity in dietary patterns, socioeconomic status, comorbidities, and medical care in hospital, from one country to another or even within the same country, play a role in causing variations in the prevalence of malnutrition in different studies. Also, the choice of measures used to define malnutrition in children obviously affects the prevalence rates detected, as is also apparent from the use of different measurements in our population. In addition, the differences in prevalence rates may be related to the heterogeneity of study populations, different criteria for malnutrition and different approaches to nutritional management.
Children are especially threatened by malnutrition, because of the high protein-energy cost of growth. So while the results of these different studies are difficult to compare, all have indicated that the prevalence of malnutrition among hospitalized children is still high and has not decreased over the past 15 years.

In conclusion, our study shows that the prevalence of malnutrition among hospitalized children is relatively high. This warrants attention because malnutrition among hospitalized children is an even more severe threat, not only for immediate survival, but also for growth, long-term development and health outcomes (e.g. high susceptibility to infection, delayed wound recovery, muscle weakness, and inability to cope with stress). This situation may lead to longer hospital stay and results in increased cost to the hospital and society. Therefore, the development and implementation of effective strategies for detection and treatment of malnutrition in paediatric patients, appropriate governmental policies and education regarding different, balanced and sufficient nutrient intake is of the utmost importance.

\section{Acknowledgement}

The authors thank the Research Vice Chancellor of Tabriz University of Medical Sciences for the financial support.

\section{References}

1. Dogan $\mathrm{Y}$ et al. Nutritional status of patients hospitalized in pediatric clinic. The Turkish Journal of Gastroenterology, 2005, 16(4):212-216.

2. Hankard R et al. Nutritional status and risk in hospitalized children. Archives of Pediatrics, 2001, 8(11):1203-1208.

3. Waitzberg DL, Caiaffa WT, Correia MITD. Hospital malnutrition: the Brazilian national survey(IBRANUTRI): a study of 4000 patients. Nutrition, 2001, 17(7\&8):573-580.

4. Correia MITD, Waitzberg DL. The impact of malnutrition on morbidity, mortality, length of hospital stay and costs evaluated through a multivariate model analysis. Clinical Nutrition, 2003, 22:235-239.

5. Wakahara T et al. Nutritional screening with Subjective Global Assessment predicts hospital stay in patients with digestive diseases. Nutrition, 2007, 23(9):634-639.

6. Yamauti AK et al. Subjective global assessment of nutritional status in cardiac patients. Arquivos Brasilieros de Cardiologia, 2006, 87(6):707-712.

7. Sungurtekin $\mathrm{H}$ et al. Comparison of two nutrition assessment techniques in hospitalized patients. Nutrition, 2004, 20:428-432.

8. Ferreira HS, França AOS. Evolução do estado nutricional de crianças submetidas a internacao hospitalar [Evolution of nutritional status in hospitalized children]. Jornal de Pediatria, 2002, 78:491-496.

9. Baker S. Protein energy malnutrition in the hospitalized patient. In: Walker WA, Watkins JB, Duggan C, eds. Nutrition in pediatrics, 3rd ed. London, BC Decker Inc Hamilton, 2003:910-916.

10. Needleman RD. Assessment of growth. In: Behrman RE, Kliegman RM, Jenson HB. Nelson textbook of pediatrics, 16th ed. Philadelphia, WB Saunders, 2000:57-61.

11. Pawellek I, Dokoupil K, Koletzko B. Prevalence of malnutrition in paediatric hospital patients. Clinical Nutrition, 2008, 27:72-76.

12. Cruz JR et al. Estado nutricional de niños preescolares guatemaltecos hospitalizados por infecciones respiratorias agudas
[Nutritional status of Guatemalan preschool children hospitalized for acute respiratory infections]. Archivos Latinoamericanos de Nutricion, 1989, 39:251-262.

13. Tienboon P. Nutritional status of pediatric patients: Maharaj Nakorn Chiang Mai Hospital. Thai Journal of Parenteral and Enteral Nutrition, 1995, 6:3-14.

14. Cortes RV, Nava-Flores G, Perez CC. Frecuencia de la desnutrición en niños de un hospital pediátrico de tercer nivel [Frequency of malnutrition in children in a tertiary level pediatric hospital]. Revista Mexicana de Pediatría, 1995, 62:131-133.

15. Ozer $\mathbf{N}$ et al. Determination of malnutrition in hospitalized children. Turkish Klinial Journal of Pediatrics, 2001, 10:133-138.

16. Genel $\mathrm{F}$ et al. Prevalence of anemia and malnutrition in hospitalized cases. Turkish Klinial Journal of Pediatrics, 1997, 6:173-177.

17. Tuncbilek E, Unalan T, Coskun T. Indicators of nutritional status in Turkish preschool children: results of Turkish Demographic and Health Survey 1993. Journal of Tropical Pediatrics, 1996, 42:78-84.

18. Hendricks KM et al. Malnutrition in hospitalized pediatric patients. Current prevalence. Archives of Pediatrics and Adolescence Medicine, 1995, 149:1118-1122.

19. Hendrikse WH, Reilly JJ, Weaver LT. Malnutrition in a children's hospital. Clinical Nutrition, 1997, 16:13-18.

20. Hulst $\mathrm{J}$ et al. Malnutrition in critically ill children: from admission to 6 months after discharge. Clinical Nutrition, 2004, 23:223-232.

21. Moy RJD, Smallmann S, Booth IW. Malnutrition in a UK children's hospital. Journal of Human Nutrition Dietetics, 1990, 3:93-100.

22. Parsons $\mathrm{HG}$ et al. The nutritional status of hospitalized children. American Journal of Clinical Nutrition, 1980, 33:1140-1146.

23. Cooper A et al. Nutritional assessment. An integral part of the preoperative pediatric surgical evaluation. Journal of Pediatric Surgery, 1981, 16:554-560. 